\title{
E-waste transboundary movement violating environmental justice
}

\author{
J.-h. Kim \\ Department of Public Administration, Seo-Kyeong University, \\ South Korea
}

\begin{abstract}
This study examined the problems in the transboundary movement of e-waste with respect to the process of the importation and treatment of e-waste (electronic waste), from the point of view of environmental justice. If the relationships between e-waste-exporting countries and -importing countries is considered in terms of their economic interests, various positive factors surface. If the problem is considered from the standpoint of environmental justice, however, both countries are guilty of complicity. In the short-term economic interests, if these are understood in terms of economic justice, e-waste importation is still not recommended; and if it is considered in the context of environmental justice, it is clearly an international criminal act. In this context, this study also suggested why this problem requires another policy, in response to the WTO system that controls international trade.

Keywords: electronic waste, hazardous wastes, environmental justice, human right, global environmental governance, basel convention, WTO.
\end{abstract}

\section{Introduction}

Recently, the UN Commission on Human Rights addressed the links between the environment and human rights, by concluding that everyone has the right to live in a world free from toxic pollution and environmental degradation. Due to economic reasons, however, many small and significant cases violating such primary human rights occur. Constructing or operating environmentally hazardous sources or facilities in economically poor areas is an environmental injustice and cannot simply depend on the market mechanism. This is because the act of discriminately violating man's primary environmental right can never be accepted by reason of unequal economic status. 


\section{Environmental justice versus economic injustice}

\subsection{Environmental justice}

Environmental problems between humans and nature can be understood in the same context as other problems of human society, such as inequality, racial discrimination, and sexual discrimination [1]. As with other social problems, solutions to environmental problems in the context of justice could be proposed. In this context, environmental justice could be understood as a basic human right, or in other words, calling for fair treatment and meaningful involvement [5].

\subsubsection{Fair treatment}

The object of fair treatment can be seen from the personal point of view. This means my social and economic group, to which I belong, such as my race and my nation, should not be treated inappropriately in any occasion. Likewise, this norm may be taken to mean that I should not experience discriminatory treatment with respect to environmental human rights due to the characteristics of my private position. It may have come to mean that it is unjust to undermine environmental rights due to race, nationality and other standards of one's socioeconomic group and position.

\subsubsection{Meaningful involvement}

Meaningful participation may be approached from the 'relative' point of view. This means relationships with other parties should be open so that the parties' mutual interests will be appropriately satisfied. In other words, benefits and losses of one party must be compared with those of the other party, and both parties must participate in decision-making to maximize their benefits and minimize their losses. This is to say that, to realize environmental justice, environmental information in mutual relationships should be open, the interested parties must fairly and substantially give inputs to the decision-making process to come up with relevant environmental regulations, and the decision-makers should be required to monitor the impacts of their decisions.

\subsubsection{Environmental justice as human right}

Therefore, environmental justice can be regarded as a goal of the entire human races. Environmental rights should be secured without any form of discrimination based on people's nationality, race or socio-economic level. Moreover, people should be able to access information when their environmental rights are in danger of attack by other parties, and there must be a system that would prepare them to make a significant response against the threat.

\subsection{Economic injustice}

The ideal scenario of environmental justice painted above is in crisis, however, due to the today's economic injustice. For example, consider cases involving hazardous waste. According to the United Nations Environment Programme 
(UNEP), about 0.3 to 0.5 billion tons of hazardous wastes are produced throughout the world every year and about $80-90 \%$ of these are produced in industrial countries [4]. Under these circumstances, the Basel Convention widely limited the free trade of hazardous waste through the Basel Convention on the Control of Transboundary Movements of Hazardous Waste and Their Disposal, and clearly stated that rich countries have a responsibility not to externalize their pollution treatment cost to poor foreign countries through imports. Due to the economic benefits of the transboundary movement of hazardous waste to both developed and developing countries, however, it persists to this day and is in fact becoming more serious. This scenario is analyzed below from the point of view of economic injustice.

\subsubsection{Injustice of developed countries}

Most developing countries support the restriction of transboundary movement of hazardous waste based on the Basel Convention, but some developed countries still oppose its ratification. For example, the U.S. signed the Basel Convention in 1989 but has not ratified it yet. This is because if a developed country exports its hazardous waste to developing countries, it can sidestep its strict domestic regulations and standards, which will lead to huge savings on disposal costs of hazardous substances and increased economic benefits. At the very reason, however, transboundary movement of hazardous waste is not actively regulated on the grounds of 'recyclability,' although this still reeks of economic injustice.

\subsubsection{Injustice of developing countries}

In the transboundary trade of hazardous waste, the economic benefits of developing countries cannot be denied as well. In the process of recycling the hazardous waste as resources, even in a poor condition, many jobs can be created for simple labourers who have been unemployed, and other economic benefits can be reaped. In particular, developing countries that lack resources to manufacture products are strongly tempted to take such direct and indirect economic benefits. In the same manner that there are many reasons that make it difficult to forbid international trading of illegal drugs, there are also, for developing countries, two sides to the thorough restriction of imports of hazardous waste. Although the importation of hazardous waste is legally forbidden, it is difficult to expect execution of the law considering the blind points in the system, namely, the acceptance of bribes by the officers who are supposed to control such trade, and the economic benefits derived by the nation. Therefore, the temptations posed by the short-term economic benefits to developing countries of the importation of hazardous waste result in economic injustice, which undermines environmental justice even as it obstructs long-term development and brings with it environmental damages and dangers to people's health.

\subsection{Injustice of e-waste trade}

In effect, the economic injustice of the transboundary movement of hazardous waste is the result of the improvement of the total amount of mutual economic 
benefits between the developed country and the developing country, which are difficult to separate between the assailant and the victim. In particular, if there is a way for a developed country to export its harmful waste to a developing country, the developed country will issue a disincentive to the developing country it will effect as a "disincentive" which discourages the developed country to invest in new technology to reduce such hazardous waste or a recycling technology, so that it would have to produce more hazardous substances. From the point of view of environmental justice, however, the transboundary movement of hazardous waste is the violation of the environmental rights of developing countries to maximize the benefits of developed countries. Even domestically, it could be argued that the economically strong violate the environmental justice of the economically weak. Therefore, this study aims to consider the transboundary movement of e-waste from the point of view of environmental justice, and, in particular, to further study the current status of imports and treatment of e-waste in China from the same standpoint.

\section{Current imports and treatment status of e-waste in China}

The problem of importation and treatment of e-waste in China has already been pointed out by Green Peace, a representative international environmental NGO, and BAN (Basel Action Network) with respect to the Guiyu area in Guangzhou Province, as earlier mentioned. Not only CCTV in China but other media outfits all over the world have started to publicize the seriousness of the problem. This study focuses, however, on the fact that this problem is not that of a limited area in Guiyu in southern China, but is already a critical problem that widely occurs in various regions in Asia. From an in-depth field research in Taizhou, China which is fast growing as an e-waste treatment hub from its previous virtual anonymity, the issues discussed further below have arisen.

This survey team was accompanied by the Green Peace activist who raised the problem. Although there was a possibility that problems would arise in the team's search for accurate spots in the field and in its interviews with the workers, which could have raised sensitive issues, the team was able to finish the survey within the limited six days from October 14, 2004 it had, with the help of a local high school teacher and some students.

\subsection{Introduction to Taizhou, China}

Taizhou, a small port city on the coast of the China Sea five hours away from Shanghai, has rapidly developed, in the last 10 years, into an industrial city amidst rural communities. The rapid growth of this city was due to the presence therein of many recycling companies utilizing waste resources imported from all over the world, which formed a huge recycling industry cluster that is expected to expand even more in the future. This area already has a serious air and water pollution problem, though. Moreover, at night-time and on weekends, when government officials do not work, large volumes of waste are illegally incinerated. In many areas of the city, residuals of illegal incinerations and 
landfills can be found. Taizhou is a very active region, however, not only in its metropolitan area but also in its farming area. Many of its residents work hard to make a living, and many people move to the city from inland China to work in Taizhou's labour-intensive recycling industry.

\subsection{Current status of e-waste in Taizhou}

\subsubsection{Amount of e-waste imports}

Since the importation of waste resources started in the ports of Taizhou in 1992, Taizhou's volume of imports has drastically increased from less than 10,000 tons to 860,000 tons in $2001,980,000$ tons in 2002 , and $1,350,000$ tons in 2003 . The said volume is expected to grow further to 1,500,000 tons at the end of 2004 . According to relevant statistics pertaining to Taizhou for 2003, of the total volume of its imports through its ports, approximately $85 \%$ is known to account for imports of waste resources. It can be said, therefore, that the recycling of waste resources in Taizhou is becoming its leading infrastructure industry. Therefore, although it is difficult to confirm Taizhou's actual volume of e-waste imports, it can be assumed that a considerable volume of e-waste would be included in its annually imported 1,500,000 tons of waste resources. Assuming that the ratio of e-waste to the total volume of Taizhou's waste resource imports is about $4.5 \%$ based on the findings from the inspection conducted by Taizhou's customs authorities, it is possible to estimate that Taizhou imported around 67,500 tons of e-waste in 2004.

\subsubsection{Scale of revenues from e-waste and regulatory difficulties}

It is normally estimated that about $0.1 \mathrm{~g}$ of gold is extracted from $1 \mathrm{~kg}$ of waste electronic goods. Considering that Taizhou imports about 67,500 tons of e-waste a year, the economic value of the gold that could be extracted from such e-waste would be around 6 billion Yuan in Chinese currency. Among other major valuable metals extracted from waste, the combined economic value of palladium ( $1 \mathrm{~g}=60$ Yuan) and silver ( $1 \mathrm{~g}=20$ Yuan) reaches up to about 10 billion Yuan, or an estimated 1.3 billion US dollar. This huge scale of revenues has become the fundamental ground that makes actual control ineffective, although the Chinese government has pronounced it as illegal. Moreover, since most e-waste is illegal imports, it is impossible to make appropriate investments for their proper treatment, so that they are eliminated through illegal incineration and illegal landfills. On the whole, this illegality has resulted in the more serious release of hazardous substances and worse air pollution not only in places in China but also in the neighbouring countries, as it is carried in the air and covers it with hazardous substances. Further, it adds to the environmental pollution cost of all Asian societies.

\section{Critical factors in the movement of e-waste}

\subsection{Crises in the e-waste-exporting countries (developed regions)}

The e-waste exporting country can misconceive that it is reaping economic benefits with the increase in the profits of relevant exporters within the country. 
The exporting country should not overlook, however, possible crises it could experience in terms of the following three aspects.

\subsubsection{Obstruction in the development of environmental technology}

Export of e-waste significantly obstructs the development of relevant technologies in industrial countries. In other words, it makes it difficult for environmentally friendly production technologies to be developed, which weakens industry productivity and obstructs its consistent growth. In particular, as developed countries transfer their treatment of wastes to developing countries as waste exports, the appropriate treatment regulation standards become helpless (i.e., loopholes concerning the regulations increase), making environmentally friendly companies bankrupt and possibly resulting in obstructing further environmental technology development or investments.

\subsubsection{Reduction of domestic jobs}

Exporting e-waste to developing countries instead of treating them means taking jobs away from the domestic low-wage working class. Since most e-waste disassembly processes are labour-intensive, they usually pay relatively low wages. Therefore, the export of e-waste to developing countries ultimately results in the closing of workplaces in waste treatment companies and recycling companies, which employ many domestic workers. Although revenues would increase from exports of e-waste, the serial bankruptcy of recycling companies will result in a more vicious cycle of negative socio-economic repercussions.

\subsubsection{Spread of environmental pollution and the boomerang effect}

In the process of developed countries exporting e-waste to other countries, they could misjudge that their environment has become better since they have removed e-waste from their country. As their neighbouring countries, however, which imported their e-waste, treat the e-waste using very dangerous methods under poor conditions, secondary- and third-level pollution arises in series. Since such series of pollutions may contaminate the e-waste-exporting countries' skies and seas, export of e-waste can bring about the boomerang effect of environmental pollution. For example, as in the case above, the e-waste flown in to the agricultural communities of China cause serious water pollution as they are reprocessed as large volumes of hydrochloric acid and chemical substances, which will contaminate coastal areas and pollute the ocean, contaminating the fish on Japanese dinner tables with heavy metals and exposing the Japanese to Itai-Itai disease. The diverse dangers that e-waste-exporting countries may face are summarized in Table 1 below.

\subsection{Crises in e-waste-importing countries (developing regions)}

On the part of e-waste-importing countries, they could misapprehend that e-waste importation would benefit them in terms of huge economic benefits, more jobs, and improved supply and demand of raw materials. These countries should also bear in mind, though, that they will also suffer very difficult losses. 
Table 1: $\quad$ Costs of e-waste exporting countries.

\begin{tabular}{|c|c|}
\hline \multirow{3}{*}{$\begin{array}{l}\text { Obstruction of } \\
\text { the development of } \\
\text { environmental } \\
\text { technologies }\end{array}$} & $\begin{array}{l}\text { With the increase in loopholes in the appropriate } \\
\text { treatment regulations due to waste exports, disincentives } \\
\text { to technology development and investment increase. }\end{array}$ \\
\hline & $\begin{array}{c}\text { Weakening of industrial productivity due to the } \\
\text { obsolescence of environmentally friendly production } \\
\text { technologies }\end{array}$ \\
\hline & $\begin{array}{l}\text { Despite the increased use of hazardous substances, } \\
\text { relevant regulations and policies would fail. }\end{array}$ \\
\hline \multirow{3}{*}{$\begin{array}{l}\text { Shrinkage of } \\
\text { domestic recycling } \\
\text { businesses }\end{array}$} & $\begin{array}{l}\text { Increase in unemployment in recycling companies and of } \\
\text { low-wage workers }\end{array}$ \\
\hline & Increase in waste factors of resources \\
\hline & $\begin{array}{l}\text { Harm to infrastructure for the construction of the base for } \\
\text { a sustainable zero-waste society }\end{array}$ \\
\hline \multirow{3}{*}{$\begin{array}{c}\text { Spread of } \\
\text { environmental } \\
\text { pollution and } \\
\text { boomerang effect of } \\
\text { such pollution }\end{array}$} & Increase and spread of air pollution \\
\hline & $\begin{array}{l}\text { Harm to health due to the spread of various hazardous } \\
\text { substances }\end{array}$ \\
\hline & $\begin{array}{l}\text { Rapid increase in respiratory diseases such as asthma in } \\
\text { neighbouring e-waste-exporting countries such as Japan }\end{array}$ \\
\hline
\end{tabular}

\subsubsection{Problems with local residents' health}

E-waste-importing companies cannot process e-waste under good conditions and through proper processes. As they extract valuable substances under poor conditions and produce large amounts of hazardous substances in the process, not only the workers in their area but also the local residents face the risk of health problems due to serious environmental pollution. Diseases would occur due to land and underground water pollution, and food shortage would get worse due to the shrinkage of agricultural activities. For example, according to the results of the survey conducted and presented by Shantou University Medical School in Shantou, Guangzhou Province, China in February 2004, sample deposits collected in the Guiyu region, where the e-waste industry started in 1990, earlier than in Taizhou, showed heavy metal pollution 1,338 times higher than chrome standards and 212 times higher than lead standards.

Huge amounts of carcinogenic substances have already contaminated the water and land in those areas, and directly affected some 311 people with ewaste-industry-related jobs, $34.1 \%$ of them now with diseases in the nervous system, $24.9 \%$ with digestion problems, and $15.7 \%$ with respiratory diseases. The ratio of people experiencing headaches and dizziness has already exceed $35.7 \%$ (data from Green Peace). 
Table 2: $\quad$ Costs of e-waste-importing countries.

\begin{tabular}{|c|c|}
\hline \multirow{3}{*}{$\begin{array}{l}\text { Problems with the local } \\
\text { residents' health due to } \\
\text { environmental pollution }\end{array}$} & $\begin{array}{c}\text { Occurrence of diseases due to land pollution and } \\
\text { underground water contamination }\end{array}$ \\
\hline & $\begin{array}{l}\text { - More serious food problems due to the shrinkage of } \\
\text { agricultural activities } \\
\text { - Lack of drinking water }\end{array}$ \\
\hline & $\begin{array}{c}\text { Occurrence of diseases caused by environmental } \\
\text { pollution such as Itai-Itai disease }\end{array}$ \\
\hline \multirow{3}{*}{$\begin{array}{l}\text { Natural disasters due to } \\
\text { irrecoverable } \\
\text { environmental conditions }\end{array}$} & Expansion of barren areas where people cannot live \\
\hline & $\begin{array}{c}\text { Geometrically progressive increase in future } \\
\text { environmental restoration costs due to environmental } \\
\text { pollution }\end{array}$ \\
\hline & $\begin{array}{c}\text { Possibility of unpredictable aftermath of pollution } \\
\text { from hazardous substances }\end{array}$ \\
\hline \multirow{3}{*}{ Social unrest } & $\begin{array}{l}\text { Resistance of the local community to serious } \\
\text { environmental pollution }\end{array}$ \\
\hline & $\begin{array}{l}\text { Tightening of external international environmental } \\
\text { regulations such as trade restrictions }\end{array}$ \\
\hline & $\begin{array}{c}\text { Large-scale unemployment and occurrence of various } \\
\text { political instabilities due to the sudden environmental } \\
\text { regulatory measures }\end{array}$ \\
\hline
\end{tabular}

\subsubsection{Natural disaster due to irrecoverable status of natural environment restoration}

The mortal pollution in the natural environment due to e-waste impoverishes the neighbouring areas within 10 years and makes ecological restoration impossible. Concerning the Guiyu region, where e-waste imports began earlier than in Taizhou, there is already a report that there are areas therein that have become barren, i.e., where people can no longer reside due to serious environmental pollution [3]. If restoration of the polluted area is attempted in the future, the restoration cost would reach astronomical figures; and if restoration is not undertaken, an unpredictable aftermath could occur due to the constant outflow of hazardous substances.

\subsubsection{Social unrest}

If this level of environmental pollution continuously occurs due to imports of ewaste, it will give rise to the resistance of local residents and to international pressure for environmental regulation by neighbouring companies. Although these kinds of dangerous factors were but anticipated in the researcher's field survey in October 2004, they have already come true only six months later in April 10, 2005, when a large-scale riot occurred in Huasi village in Dungyang city near the Taizhou region, involving 30,000 local residents who opposed the increase of environmentally polluting factories in the village and 3,000 
policemen who attempted to control them (Chosun Daily Newspaper, April 13, 2005). Moreover, in Zhansha village near Taizhou, a fierce demonstration and collision were reported in June 2005, which were related to the issue of environmental pollution (Kookmin Daily Newspaper, July 4, 2005).

\section{Conclusion}

This study examined the problems in the transboundary movement of e-waste with respect to the process of the importation and treatment of e-waste, especially focusing on Taizhou, Zhejiang Province, China, from the point of view of environmental justice and economic injustice. If the relationships between e-waste-exporting countries and -importing countries in considered in terms of their economic interests, various positive factors can be surfaced. If the problem is considered from the standpoint of environmental justice, however, both countries are guilty of complicity.

On the short-term economic interests, if these are understood in terms of economic justice, e-waste importation is still not recommended; and if it is considered in the context of environmental justice, it is clearly an international criminal act. This is also why this problem requires another policy, in response to the WTO system that controls international trade. The WEO (World Environmental Organization), which leads in raising public awareness of international environmental matters on behalf of entire societies worldwide, in response to the private principle of maximizing economic benefits, can push for Global Environment Governance to realize environmental justice in response to economic injustice, and this is expected to become a major issue in relevant domestic and international environmental policies in the future.

Therefore, future Global Environmental Governance have to be undertaken to restrain the economic benefits maximization theory in the world trade order that stimulates globalization and openness. Such policy would make it possible to expect mandating of active regulations in some areas where mutual economic interests of developed and developing countries are met. The interests-oriented relationship of e-waste-exporting and -importing countries could be beneficial to both in the short term. Since it could impose significant costs on them all in the long term, however, the environmental regulations of each country on this matter should be approached not in the context of domestic private interests but from the standpoint of primary human rights; and if these regulations are violated, such violations should be treated as international criminal acts.

All humans should be fairly treated regardless of their nationality or socioeconomic group. To ensure meaningful response to the relevant environmental pollution problem, each government should approach and design their environmental policies and systems in a new light. The starting point in overcoming this world's environmental crisis is the renewed protection of environmental rights, which are primary human rights regardless of nationalities and socio-economic status. 
104 Management of Natural Resources, Sustainable Development and Ecological Hazards

\section{References}

[1] Han, Myeon-hee, A Theory of Green Civilization, Dongnyeok Press: Seoul. 2004.

[2] Kim, Jung-hoon, Sustainable Urban Waste Management System in Metropolitan Seoul. The Sustainable City III. WIT Press: UK. 2004.

[3] Lee, Sherry, Ghosts in the Machines in South China Morning Magazine. May 12, 2002: HK.

[4] McGinn, Anne P., Reducing Our Toxic Burden, State of the World. WWI. Norton Co.: NY. 2002.

[5] Rawls, John, A Theory of Justice. Revised edition. Harvard University Press: MA. 1999.

[6] Tieenberg, T., Environmental and Natural Resources Economics. Addison Wesley Co.: NY. 2002. 